\title{
UPAYA MENINGKATKAN PRESTASI BELAJAR BAHASA INDONESIA DALAM MATERI MEMBACA DENGAN METODE ROLE PLAYING DI KELAS XI SEKOLAH LUAR BIASA NEGERI SUKANAGARA KABUPATEN CIANJUR
}

\author{
Uce Solihati, M.Pd \\ SLB Negeri Sukanagara Cianjur, ucesolihati30@gmail.com
}

\begin{abstract}
Child with Intelectual Disability (ID) is a child below average intelligence, experiences behavioral obstacles, adjustments and occurs during his development. Childrens with Intellectual Disability are often equated with mentally retardation terms (Feeble Minded). Reading using the role playing method is one of the main lessons that teachers give to children at school. The lesson, which is a part of Bahasa course, is given early as a basis for further learning. Children who cannot read yet have difficulty following other lessons. The purpose of this classroom action research is entitled "Efforts to Improve Achievement of Learning Indonesian in Reading Material by Applying the Role Playing Method in Class XI SLB Negeri Sukanagara, Cianjur Regency " is to get an overview of the implementation of learning Indonesian in reading in children at SMPLB SLB N Sukanagara, Cianjur Regency and the difficulties faced by the teacher. in improving the implementation of learning to read in mentally retarded children. In this classroom action research the subjects of this study were five students with in class XI and the data collection techniques used were observation and test. Furthermore, the research results were analyzed using quantitative and qualitative analysis techniques.
\end{abstract}

\section{Keywords:}

Learning, Reading, Role Playing Method, Children with Impairment

\begin{abstract}
Abstrak
Anak Tunagrahita adalah anak yang memiliki kecerdasan di bawah rata-rata, mengalami hambatan tingkah laku, penyesuaian dan terjadi pada masa perkembangannya. Anak tunagrahita sering disepadamkan dengan istila-istilah lemah pikiran (feebleminded) terbelakang mental (Mentally Retarded). Membaca dengan menggunakan metode role playing merupakan salah satu pelajaran yang utama yang diberikan guru kepada anak di sekolah. Pelajaran bahasa Indonesia ini lebih awal diberikan karena merupakan dasar untuk belajar lebih lanjut. Anak yang belum bisa membaca memiliki kesulitan dalam mengikuti pelajaran yang lainnya. Tujuan dari penelitian tindakan kelas ini berjudul "Upaya Meningkatkan Prestasi Belajar Bahasa Indonesia Pada Materi Membaca Dengan Menerapkan Metode Role Playing DI Kelas XI Sekolah Luar Biasa Negeri Sukanagara Kabupaten Cianjur" adalah untuk mendapatkan gambaran tentang pelaksanaan pembelajaran bahasa Indonesia dalam membaca pada anak tunagrahita di Sekolah Menengah Pendidkan Luar Biasa Negeri Sukanagara Kabupaten Cianjur ini serta kesulitan-kesulitan yang dihadapi guru dalam meningkatkan pelaksanaan pembelajaran membaca pada anak tunagrahita. Dalam penelitian tindakan kelas ini subjek penelitian ini adalah 5 orang peserta didik tunagrahita kelas XI dan teknik pengumpulan data yang digunakan adalah observasi dan test. Selanjutnya hasil penelitian di analisis dengan teknik analisa kuantitatif dan kualitatif.
\end{abstract}

Kata Kunci:

Pembelajaran, Membaca, Metode Role Playing, Anak Tunagrahita 


\section{PENDAHULUAN}

Dalam proses belajar mengajar di kelas guru hendaknya lebih kreatif dalam memilih metode pembelajaran yang sesuai dengan materi serta kondisi lingkungan dimana guru itu mengajar. Pemilihan dan pengetahuan metode pembelajaran yang sesuai dengan karakteristik materi yang diajarkan serta diharapkan memudahkan peserta didik dalam memahami materi. Selain itu peserta didik lebih berperan aktif dalam proses belajar mengajar.

Selama ini peserta didik selalu terkondisikan untuk menerima informasi tanpa berusaha menemukan informasi tersebut. Hal ini menyebabkan peserta didik hanya mampu untuk menghapal tampa memahami materi yang telah diterimanya. Oleh sebab itu agar peserta didik lebih biasa lagi mengasah kreatifitasnya diperlukan sebuah metode pembelajaran yang menekankan kreatifitas peserta didik.

Dengan diterapkannya variasi metode pembelajaran diharapkan menumbuhkan motivasi dan minat peserta didik dalam proses belajar mengajar untuk meningkatkan prestasi belajarnya. Salah satu pembelajaran yang menekankan pada keaktifan peserta didik di dalam pembelajaran mengutamakan interaksi penguasaan materi yang telah ditugaskan oleh guru. Sebagaimana dijelaskan dalam UndangUndang Republik Indonesia Nomor 20 Tahun 2013 tentang sistem Pendidikan Nasional yang dapat disimpulkan bahwa negara memberikan jaminan sepenuhnya kepada anak berkebutuhan khusus untuk memperoleh layanan pendidikan yang bermutu. Hal yang sama dengan anak yang normal dalam memperoleh pendidikan.

Anak berkebutuhan khusus sebagaimana warga negara lainnya memiliki hak yang sama dalam memperoleh pendidikan dan pengajaran, hal ini diperkuat dengan UU No.8 tahun 2016 tentang hak-hak penyandang disabilitas dalam layanan pendidikan pada berbagai jenis dan jenjang pendidikan agar penyandang disabilitas atau anak berkebutuhan khusus dapat mengakses pendidikan sesuai bakat, minat dan kapasitas kemampuannya.

Dalam era globalisasi setiap bangsa perlu meningkatkan daya saingnya di dalam berbagai bidang, termasuk sumber daya manusia secara umum, tetapi anak berkebutuhan khusus yang merupakan bagian dari masyarakat indonesia tidak bisa menghindari diri dari proses globalisasi tersebut, anak berkebutuhan khusus dituntut untuk memiliki keterampilan untuk ikut bersaing ditengah perkembangan dunia yang kian kompetitip di masa kini dan masa depan. Oleh karena itu pelayanan yang diberikan kepada anak harus disesuaikan dengan kemampuan dan kebutuhan anak tersebut. Kenyataan di lapangan peneliti mengadakan observasi di Sekolah Luar Biasa Negeri Sukanagara Kabupaten Cianjur, bahwa anak tunagrahita memerlukan perhatian yang lebih dari gurunya dalan hal ini anak mengalami hambatan dalam belajar dan hambatan perkembangan. Anak tunagrahita memiliki tingkat yang berbeda, seperti tunagrahita ringan, sedang, dan berat. Anak tunagrahita juga mengalami hambatan dalam perkembangan komunikasi, sehingga mereka mengalami hambatan dalam pelajaran akademik seperti membaca dan hambatan bersosialisasi dalam kehidupan sehari-hari. Oleh karena itu harus diberikan beberapa materi pelajaran seperti membaca.

Membaca merupakan salah satu pelajaran yang utama dan pertama yang diberikan guru kepada anak di sekolah. Pengajaran membaca ini lebih awal diberikan, karena dasar untuk 
belajar lebih lanjut. Anak yang belum bisa membaca memiliki kesulitan dalam mengikuti pelajaran yang lainnya. Salah satu bagian dari mebaca adalah membaca teks, yaitu bacaan sederhana dengan penerapan metode role playing yang menjelaskan tentang permainan dalam pembelajaran dengan memainkan peran tokoh-tokoh hayalan serta berkolaborasi untuk membuat sebuah cerita bersama, seperti yang dikatakan Santosa (2016:32) yang menyatakan bahwa role playing adalah sejenis permainan gerak yang di dalamnya atau tujuan, aturan dan sekaligus melibatkan unsur senang.Belajar terutama membaca dengan menerapkan role playing yang merupakan suatu cara penguasaan bahan-bahan pelajaran melalui pengembangan imajinasi dan penghayatan peserta didik dalam kegiatan belajar mengajar, sehingga diharapkan peserta didik dapat meningkatkan keterampilan dan pemahaman dalam belajar. Berdasarkan uraian di atas penulis tertarik untuk mencoba melakukan penelitian pada anak tunagrahita kelas XI di Sekolah Luar Biasa Negeri Sukanagara Kabupaten Cianjur.

\section{METODE}

Penelitian ini dilakukan dalam memecahkan permasalahan yang terjadi selama proses pembelajaran di kelas dengan menerapkan sebuah model pembelajaran untuk mengatasi permasalahan yang terjadi. Metode penelitian yang digunakan adalah metode tindakan kelas (PTK).

Penelitian tindakan kelas (PTK) menurut Arikunto $S$ (2010:2) menerangkan tiga pengertian penelitian tindakan kelas, yaitu:

1. Penelitian; menunjukkan pada suatu kegiatan mencermati suatu objek dengan menggunakan cara dan aturan metodologi tertentu untuk memperoleh data atau informasi yang bermanfaat dalam meningkatkan mutu suatu hal yang menarik minat dan penting bagi peneliti.

2. Tindakan; menunjuk pada sesuatu gerak kegiatan yang sengaja dilakukan dengan tujuan tertentu. Dalam penelitian ini berbentuk rangkaian siklus kepada siswa.

3. Kelas; dalam hal ini tidak terikat pada pengertian ruang kelas, tetapi dalam pengertian yang lebih spesifik. Seperti yang sudah lama dikenal dalam bidang pendidikan dan pengajaran, yang dimaksud dengan istilah kelas adalah sekelompok siswa yang dalam waktu yang sama, menerima pelayanan yang sama dari guru yang sama.

Sedangkan menurut Kusnandar (2011:46) Penelitian Tindakan Kelas adalah sebuah bentuk kegiatan refleksi diri yang dilakukan oleh para pelaku pendidikan dalam suatu situasi kependidikan untuk untuk memperbaiki rasionalitas. Ini dapat didefinisikan sebagai suatu bentuk kajian yang bersifat reflektif oleh pelakau tindakan yang dilakukan untuk meningkatkan pemahaman terjadap tindakan yang dilakukan serta memperbaiki kondisi dimana praktek-praktek pembelajaran tersebut dilakukan.

Penelitian Tindakan Kelas yang berasal dari istilah inggris Classroom Action Research yang berarti penelitian dilakukan pada sebuah kelas untuk mengetahui akibat tindakan yang ditetapkan pada satu subjek penelitian di kelas tersebut.

Dari definisi tersebut, PTK merupakan studi sistematika terhadap praktek pembelajaran di kelas dengan tujuan untuk memperbaiki atau meningkatkan kualitas praktek pembelajaran dan hasil belajar peserta didik secara berkesinambungan dengan melakukan tindakan tertentu. 
Secara garis besar terdapat empat tahapan yang lazim digunakan dalam penelitian tindakan kelas, yaitu: (1) Perencanaan, (2) Pelaksanaan,(3) Pengamatan,

Refleksi.Tahapan ini dilakukan dalam sebuah siklus, yaitu satu putaran kegiatan beruntun dari tahap penyusunan rancangan sampai dengan refleksi.

(1) Perencanaan.

Pada tahap ini akan dibuat proses rancangan penelitian tiap siklus oleh peneliti. Tahap yang dilakukan dalam proses perencanaan ini adalah membuat rencana pelaksanaan pembelajaran yang akan dilakukan membuat tabel observasi untuk observer, dan membuat angket untuk dibagikan kepada peserta didik nanti, serta tindakan dan pengamatan yang dilakukan dalam proses pelaksanaan, perencanaan tiap siklus 1 , siklus 2, dan seterusnya terdapat pada lembar instrumen.

(2) Pelaksanaan

Pelaksanaan yang dilakukan adalah tindakan dari rencana pelaksanaan pembelajaran yang telah dibuat. Kegiatan ini untuk meningkatkan kemampuan operasi bilangan dengan model pembelajaran bimbingan belajar, yang disesuaikan dengan direncanakan dalam rencna pelaksanaan pembelajaran. Tindakan tiap siklus 1 , siklus 2 dan sterusnya terdapat pada lembar instrumen.

(3) Pengamatan

Pengamatan yang dilakukan mencakup siklus 1 , siklus 2, dimana pengamatan ini untuk mengetahui, mengenali, mengamati, dan merekam kendala apa saja yang tercapai dan tidak tercapai dalam proses pembelajaran yang telah dilakukan. Pengamatan ini dilakukan secara terus menerus dengan tujuan untuk mengumpulkan data, bukti, maupun informasi yang dapat digunakan untuk perencanaan. Tahapan ini akan dijadikan masukan untuk melakukan sklus selanjutnya.

(4) Refleksi

Refleksi merupakan proses berpikir untuk melihat kembali aktivitas yang sudah dilakukan untuk mencari solusi berdasarkan hasil observasi di kelas pada saat pembelajaran berlangsung. Pada tahap ini dilakukan kegiatan menganalisis, interprestasi, dan penjelasan terhada semua informasi yang diperoleh dari pelaksanaan tindakan.

\section{SUBJEK DAN OBJEK PENELITIAN}

Yang menjadi subjek penelitian ini adalah peserta didik yang duduk di kelas XI, yakni terdiri dari 3 orang anak laki-laki dan 2 orang anak perempuan semuanya berjumlah 5 orang peserta didik.

Sedangkan yang menjadi objek penelitian adalah kemampuan peserta didik dalam melaksanakan pembelajaran bahasa Indonesia tentang membaca dengan menggunakan metode role play dengan tujuan agar peserta didik dapat membaca serta berpendapat seperti orang lain pada umumnya.

Dengan demikian pembelajaran bahasa Indonesia pada materi membaca dengan penerapan role play, maka diharapkan peserta didik dapat melakukan suatu kegiatan berbicara dimana peserta didik dalam kegiatan belajar mengajar berlangsung melakukan kegiatan demontrasi serta dapat berperan sebagai orang lain atau dirinya sendiri dalam berbagai situasi imajinatif yang mampu mengembangkan kemampuan daya cipta dan bermain sepenuhnya. 


\section{WAKTU DAN LOKASI PENELITIAN}

a. Waktu Penelitian

Sesuai dengan rencana penelitian tindakan kelas, dimana ini dilakukan melalui beberapa tahapan antara lain:

Tabel 1

Prosedur Waktu Penelitian

\begin{tabular}{|c|l|c|c|c|c|c|c|c|c|c|c|c|}
\hline \multirow{2}{*}{$\begin{array}{c}\text { N } \\
\mathrm{o}\end{array}$} & Kegiatan & \multicolumn{3}{|c|}{ Januari } & \multicolumn{5}{|c|}{ Febuari } & \multicolumn{5}{|c|}{ Maret } \\
\hline 1 & Minggu ke.. & 2 & 3 & 4 & 1 & 2 & 3 & 4 & 1 & 2 & 3 & 4 \\
\hline 2 & Perencanaan & $\mathrm{v}$ & & & & & & & & & & \\
\hline 3 & PelakSikan & & $\mathrm{v}$ & & & & & & & & & \\
\hline 4 & PelakSiklus II & & & & & $\mathrm{v}$ & $\mathrm{v}$ & & & & & \\
\hline 5 & $\begin{array}{l}\text { Pengolahan } \\
\text { Data Bab 1\&2 }\end{array}$ & & & & & & & $\mathrm{v}$ & & & & \\
\hline 6 & $\begin{array}{l}\text { Pengolahan } \\
\text { Data Bab 3 \&4 }\end{array}$ & & & & & & & & $\mathrm{v}$ & $\mathrm{v}$ & & \\
\hline 7 & $\begin{array}{l}\text { Penyusunan } \\
\text { Laporan }\end{array}$ & & & & & & & & & & $\mathrm{v}$ & $\mathrm{v}$ \\
\hline
\end{tabular}

Berdasarkan keterangan tabel di atas bahwa penelitian ini dilaksanakan pada semester 2 dan dimulai bulan Januari 2021 sampai bulan maret 2021, selama 3 bulan, dengan rincian perenacaan penelitian dilaksanakan bulan januari minggu ke 2 pada hari selasa tanggal 12 januari 2021, kemudian mengadakan persiapan pada minggu ke 3 tanggal 19 januari 2021, kemudian pelaksanaan tindakan siklus ke I dilakukan minggu ke 4 tanggal 26 bulan januari dan minggu ke 1 tanggal 2 Febuari 2021, lalu pada minggu 2 dan minggu ke 3 tanggal 2 febuari 2021 dilaksanakan penelitian siklus ke II. Sedangkan pengolahan data bab I \& 2 dikerjakan pada minggu ke 4 di bulan Febuari 2021, dan bulan Maret minggu ke 1,2 melakukan pengolahan bab 3,4, kemudian minggu ke 3,4 mei 2021 penyusunan laporan penelitian. Dengan jumlah peserta didik 5 orang. Peneliti mengadakan penelitian tindakan kelas ini ditentukan dengan penjadwalan waktu dengan harapan hasil yang akan diperoleh dari penelitian tindakan kelas ini dapat lebih objektif.

\section{b. Lokasi Penelitian}

Lokasi penelitian dalam penelitian adalah ruangan tempat berlangsungnya kegiatan belajar mengajar di Sekolah Luar Biasa Negeri Sukanagara kabupaten Cianjur.

\section{HASIL PENELITIAN}

Bahwa dengan menggunakan metode role playing diperoleh hasil yang cukup baik, sehubungan dengan pembelajaran berceritera melalui metode role play peserta didik dapat meningkatkan kemampuan berbahasa dengan berceritera berdasarkan media gambar yang diajarkan.Ini merupakan hasil pemantauan dan pengamatan terhadap pelaksanaan tindakan. Dimana paparan tersebut meliputi dua tahap yaitu tahap perencanaan, tahap pelaksanaan, dan tahap refleksi sebagai bentuk pelaksanaan tindakan. Menurut pengamatan dan pencatatan pembelajaran peserta didik di kelas XI menunjukkan bahwa peserta didik pada umumnya sangat menyenangi pembelajaran dengan menggunakan metode role play. Dari data yang mencakup data perencanaan, pelaksanaan dan tahap refleksi yang diperoleh melalui hasil observasi.

Pelaksanaan tindakan dilakukan kepada semua peserta didik, dimana dalam pelaksanaan tindakan, guru observer berperan sebagai mitra peneliti yang akan memantau, mencatat, dan mendokumentasikan semua temuan yang akan dijadikan sebagai data dan informasi yang hasilnya akan dilaksanakan pada tindakan selanjutnya. Dalam pelaksanaan tindakan ini terlebih dahulu melihat nilai bahasa (membaca) sebagai nilai awal, seperti dalam tabel di bawah ini: 
Tabel 2

Rekapitulasi Nilai Awal Bahasa Indonesia

\begin{tabular}{|c|c|c|c|c|c|c|c|c|}
\hline \multirow[t]{2}{*}{ No } & \multirow[t]{2}{*}{ Nama } & \multirow[t]{2}{*}{ KKM } & \multicolumn{2}{|c|}{$\begin{array}{c}\text { Nilai } \\
\text { pertemuan }\end{array}$} & \multirow{2}{*}{$\begin{array}{l}\text { Jum } \\
\text { lah }\end{array}$} & \multirow[t]{2}{*}{ Rata2 } & \multicolumn{2}{|c|}{$\begin{array}{l}\text { Keterang } \\
\text { an }\end{array}$} \\
\hline & & & 01 & 02 & & & $\begin{array}{l}\mathrm{T} \\
\mathrm{T}\end{array}$ & $\mathrm{BL}$ \\
\hline 1 & Dimas & 75 & 65 & 70 & 135 & 67,5 & - & $\mathrm{BL}$ \\
\hline 2 & Fauzi & 75 & 65 & 65 & 130 & 65 & - & $\mathrm{BL}$ \\
\hline 3 & Ijay & 75 & 60 & 70 & 130 & 65 & - & $\mathrm{BL}$ \\
\hline 4 & Karida & 75 & 60 & 60 & 120 & 60 & - & $\mathrm{BL}$ \\
\hline 5 & Puji P & 75 & 70 & 70 & 140 & 70 & - & $\mathrm{BL}$ \\
\hline \multicolumn{3}{|c|}{ Nilai Terendah } & 60 & 60 & 120 & 60 & & \\
\hline \multicolumn{3}{|c|}{ Nilai Tertinggi } & 70 & 70 & 135 & 65 & & \\
\hline \multicolumn{3}{|c|}{ Jumlah } & 320 & 33 & 655 & 327 & & 5 \\
\hline \multicolumn{9}{|c|}{ Presentase } \\
\hline \multicolumn{3}{|c|}{ Nilai Rata-rata } & 64 & 67 & 131 & 65,5 & & \\
\hline \multicolumn{3}{|c|}{ Peningkatan Pertemuan } & & & & & & \\
\hline
\end{tabular}

\section{Siklus ke I}

Peneliti merasa tertarik untuk meneliti dalam pembelajaran bahasa Indonesia. Peserta didik kaum anak tunagrahita tidak dapat menerima rangsangan dari lingkungan, sehingga dalam menyatakan pikiran dan keinginan mengakibatkan kesulitan, begitupun dalam pembelajaran bahasa Indonesia tentang membaca dengan menggunakan metode role play, dimana dalam pembelajaran bahasa Indonesia mencantumkan Kriteria Ketuntasan Minimal (KKM) tercantum 75, dengan jumlah peserta didik di kelas XI Sekolah Menengah Atas Luar Biasa berjumlah 5 orang yang terdiri ari 2 orang laki-laki dan 3 orang perempuan, serta dengan rekapitulasi nilai awal bahasa Indonesia yang tercantum diatas. Adapun nilai rekapitulasi siklus ke I semeter II adalah:
Tabel 3

Rekapitulasi Nilai Belajar Bahasa Indonesia Siklus I Pertemuan Pertama dan Kedua

\begin{tabular}{|c|c|c|c|c|c|c|c|c|}
\hline \multirow[t]{2}{*}{ No } & \multirow[t]{2}{*}{ Nama } & \multirow{2}{*}{$\begin{array}{l}\mathrm{KK} \\
\mathrm{M}\end{array}$} & \multicolumn{2}{|c|}{$\begin{array}{c}\text { Nilai } \\
\text { pertemuan }\end{array}$} & \multirow{2}{*}{$\begin{array}{c}\text { Jum } \\
\text { lah }\end{array}$} & \multirow[t]{2}{*}{ Rata2 } & \multicolumn{2}{|c|}{$\begin{array}{l}\text { Keteranga } \\
\mathrm{n}\end{array}$} \\
\hline & & & 1 & 2 & & & TT & $\mathrm{BL}$ \\
\hline 1 & Dimas & 75 & 75 & 75 & 150 & 75 & $\mathrm{TT}$ & - \\
\hline 2 & Fauzi & 75 & 65 & 70 & 130 & 67.5 & - & $\mathrm{BL}$ \\
\hline 3 & ljay & 75 & 60 & 70 & 130 & 65 & - & $\mathrm{BL}$ \\
\hline 4 & Karida & 75 & 65 & 65 & 130 & 65 & - & $\mathrm{BL}$ \\
\hline 5 & Puji P & 75 & 75 & 75 & 150 & 75 & $\mathrm{TT}$ & - \\
\hline \multicolumn{3}{|c|}{ Nilai Terendah } & 60 & 65 & 120 & 60 & & \\
\hline \multicolumn{3}{|c|}{ Nilai Tertinggi } & 75 & 75 & 135 & 65 & & \\
\hline \multicolumn{3}{|c|}{ Jumlah } & 340 & 355 & 655 & 327 & 2 & 3 \\
\hline \multicolumn{3}{|c|}{ Presentase } & & & & & $\begin{array}{l}40 \\
\%\end{array}$ & $\begin{array}{l}60 \\
\%\end{array}$ \\
\hline \multicolumn{3}{|c|}{ Nilai Rata-rata } & 68 & 71 & 139 & 69.5 & & \\
\hline \multicolumn{3}{|c|}{$\begin{array}{l}\text { Peningkatan } \\
\text { Pertemuan }\end{array}$} & & 3 & & & & \\
\hline
\end{tabular}

Siklus1 ini dilakukan pada hari selasa tanggal 26 januari 2021 melaksanakan siklus 1 sebanyak 2 jam pelajaran (ax40menit), menurut observer dapat dikatagorikan bahwa peserta didik dikelas XI Sekolah Menengah Atas Luar Biasa ini hanya $40 \%$ bisa mengikuti pembelajaran bahasa Indonesia dengan menggunakan metode role play, walaupun peserta didik masih perlu bimbingan, sedangkan $60 \%$ masih perlu adanya pembelajaran berupa latihan-latihan yang intensif. Juga terhadap kegiatan pembelajaran bagi peneliti harus lebih ditambah cara pelayanan secara individu agar peserta didik lebih komunikatif dalam membaca materi yang diajarkan sehingga peserta didik termotivasi dan tertarik dalam mengekspresikan serta memberikan rasa percaya dri pada setiap peserta didik. Dengan metode role play diharapkan semua peserta didik mampu membaca bahasa Indonesia dengan lancar sesuai materi yang diajarkan. 


\section{Siklus Ke II}

Merancang rencana tindakan yang dilakukan dengan menekankan pada hal yang harus diperbaiki berdasarkan hasil pada siklus ke I, maka dilakukan pada siklus ke II pada hari selasa tanggal 2 febuari 2021 sampai tanggal 16 febuari 2021, selama 2 jam (a x 40 menit) dengan membuat RPP bahasa Indonesia tentang membaca menggunakan metode rolr play, kemudian melakukan observasi dan pengolahan data pada tanggal 23 febuari 2021 secara bersamaan yang dilakukan olehpeneliti, guru dan mitra peneliti. Lalu menganalisis dan merefleksi pelaksanaan hasil tindakan pada siklus ke II, pelaksanaan analisis terhadap pembelajaran yang dilakukan, maka diperoleh gambaran hasil pembelajaran bahasa Indonesia tentang membaca seperti dalam tabel di bawah ini:

\section{Tabel 4}

Rekapitulasi Nilai Belajar Bahasa Indonesia Siklus I Pertemuan Ketiga dan Keempat

\begin{tabular}{|c|c|c|c|c|c|c|c|c|}
\hline \multirow[t]{2}{*}{ No } & \multirow[t]{2}{*}{ Nama } & \multirow{2}{*}{$\begin{array}{l}\mathrm{KK} \\
\mathrm{M}\end{array}$} & \multicolumn{2}{|c|}{$\begin{array}{c}\text { Nilai } \\
\text { pertemuan }\end{array}$} & \multirow{2}{*}{$\begin{array}{l}\text { Jum } \\
\text { lah }\end{array}$} & \multirow[t]{2}{*}{ Rata2 } & \multicolumn{2}{|c|}{$\begin{array}{l}\text { Keteranga } \\
\text { n }\end{array}$} \\
\hline & & & 3 & 4 & & & TT & B \\
\hline 1 & Dimas & 75 & 80 & 90 & 170 & 85 & TT & - \\
\hline 2 & Fauzi & 75 & 75 & 75 & 150 & 75 & TT & - \\
\hline 3 & Ijay & 75 & 75 & 75 & 150 & 75 & $\pi$ & - \\
\hline 4 & Karida & 75 & 80 & 80 & 130 & 80 & $\pi$ & - \\
\hline 5 & Puji P & 75 & 85 & 85 & 180 & 85 & $\pi$ & - \\
\hline \multicolumn{3}{|c|}{ Nilai Terendah } & 75 & 75 & 150 & 75 & & \\
\hline \multicolumn{3}{|c|}{ Nilai Tertinggi } & 80 & 90 & 180 & 85 & & \\
\hline \multicolumn{3}{|c|}{ Jumlah } & 395 & 405 & 800 & 400 & 5 & \\
\hline \multicolumn{3}{|c|}{ Presentase } & & & & & $100 \%$ & \\
\hline \multicolumn{3}{|c|}{ Nilai Rata-rata } & 79 & 81 & 160 & 80 & & \\
\hline \multicolumn{3}{|c|}{$\begin{array}{l}\text { Peningkatan } \\
\text { Pertemuan }\end{array}$} & & 2 & & & & \\
\hline
\end{tabular}

Tabel di atas menampilkan bahwa tingkat pencapaian hasil belajar selama diadakan pelajaran dengan membaca menggunakan metode role play dalam bahasa Indonesia pada siklus II tergolong baik, dimana data ini memperlihatkan adanya peningkatan hasil belajar dengan nilai tertinggi 90, dimana peserta didik mampu membaca dan runtut cara bercerita sesuai teks serta dalam sususnan kalimatnya. Dan nilai terendah 75, masih perlu bimbingan guru serta nilai rata-rata kelas 80 . Yang mencapaian KKM 75 sebanyak 2 0rang dan yang melampaui sebanyak 3 orang, tetapi mereka kaum peserta didik tunagrahita dikatagorikan tuntas $(100 \%)$ dari jumlah 5 orang peserta didik.

Pada umumnya peserta didik yang dijadikan responden sebelum ditretment menunjukkan kurang menguasai bahasa khususnya materi membaca dengan menggunakan media role playing. Hal ini terjadi kemungkinan peserta didik belum memahami dasar cara membaca dengan menggunakan media role playing, maka peneliti memberikan treatment secara individual yang diberikan dengan gambargambar dan nama tulisan dalam kartu kata.

Dapat dikatakan sebagian besar peserta didik (80\%) bias membaca gambar dengan bahasa yang sederhana sesuai karakteristik anak tunagrahita dan dalam menjawab soal dari isi ceritera bergambar yang di berikan dan (20\%) masih dalam bimbingan, hal ini menunjukkan bahwa mayoritas peserta didik mampu mencapai nilai yang cukup efektifndalam mengerjakan soal soal dalam gambar. Hal ini menunjukkan bahwa dalam meningkatkan bahasa pada peserta didik tunagrahita cukup efektif dalam membaca melalui metoda role playing peserta didik lebih komunikatif. Ini terlihat antara peserta didik dalam mengerjakan soal ceritera dimana masing-masing peserta didik berpikir dan berpartisipasi secara proaktif dalam memberikan hasil pemikirannya tentang gambar-gambar yang diberikan.

Hasil pemikirannya walaupun secara sederhana yang disesuaikan dengan kondisi peserta didik kelas XI, mereka peserta didik 
kelas XI cukup kreatif san saling tukar pikiran walaupun bahasa mereka sederhana sesuai kemampuannya. Disini dapat dijadikan suatu kegiatan belajar yang efektif, efesien, juga bias dijadikan media sosialisasi dan interaksi diantara anak-anak tunagrahita.

Proses belajar dan hasil kerja diantara peserta didik tunagrahita menunjukkan hasil yang cukup baik. Hal ini terlihat bahwa dar 3 kriteria, mereka kaum tunagrahita pada umumnya dapat dikatakan hampir (90\%) dapat membaca gambar dengan metode role playing dengan gaya bahasa yang mereka punya dan mampu mengucapkan kembali.

\section{PEMBAHASAN}

Berdasarkan observasi dari hasil penelitian terlihat bahwa anak tunagrahita kemampuan bahasa dalam membaca melalui role playing serta media gambar untuk memperjelas informasi bacaan yang disampaikan dalam kegiatan belajar mengajar berlangsung, sehingga peserta didik tidak akan kelihatan sulit untuk membayangkan bahasa dalam gambar secara abstrak. Hal ini menunjukkan bahwa anak tunagrahita memiliki daya bayang (operational thingking) sangat terbatas, sehingga dalam melihat kondisi seperti itu maka dalam membimbing anak tunagrahita dalam meningkatkan kemampuan membaca melalui role playing harus lebih optimal dilakukan, karena dari hasil observer menunjukkan kemampuan bahwa peserta didik tunagrahita sulit untuk di tingkatkan, sehingga bimbingan yang beragam harus di sesuaikan dengan karakteristik peserta didik seusianya. Juga dapat meningkatkan kemampuan anak dan kematangan berpikir dalam proses untuk mengambil keputusan hasil buah pikirannya terhadap soal membaca melalui media gambar yang diberikan dan hasil proses itu mereka anak tunagrahita mampu menghasilkan hasil yang baik. Ini ditunjukkan dengan kemampuan mereka dalam menyusun cerita gambar. Berdasarkan analisis yang telah dilakukan pada siklus I, II pada umumnya dapat dilihat bahwa rata-rata aktivitas peserta didik tiap siklus mengalami peningkatan.

Adapun dalam pelaksanaan Penelitian ada 2 aktivitas yaitu:

\section{a. Aktivitas Guru}

Berdasarkan analisis yang telah dilakukan pada siklus ke I,II pada umumnya katagori yang diperoleh guru dalam kegiatan belajar mengajar tergolong baik. Pada siklus I masukan yang diberikan observer terhadap guru peneliti yaitu tentang waktu yang harus diperhitungkan dengan sebaik-baiknya, juga media pembelajaran yang harus bervariatif sehingga peserta didik lebih antusias dan komunikatif dalam pembelajaran serta guru harus memberikan apersepsi terhadap semua peserta didik, guru observer harus memberikan koreksi terhadap kata-kata atau kalimat yang disampaikan oleh guru peneliti. Untuk memperbaiki masalah tersebut maka pembelajaran siklus I dilakukan perbaikan dengan tidak mengulang kesalahan pada siklus ke II. Pada siklus II. Pada siklus ini guru lebih memperhatika waktu, memberikan apersepsi terhadap peserta didik serta memberikan cara atau kalimat yang sesuai dengan meteri yang disampaikan guru.

Tabel 5

Hasil Analisis Aktivitas Guru

\begin{tabular}{|c|c|c|}
\hline Siklus & Rata-rata & Katagori \\
\hline I & 3,1 & Baik \\
\hline II & 3,8 & Baik \\
\hline
\end{tabular}

b.Aktivitas Siswa

Hasil Analisis terhadap aktivitas peserta didik mengalami peningkatan dari 
awal ke siklus I sampai ke siklus II. Ratarata aktivitas siswa pada awal pembelajaran tergolong "kurang" yanitu sebanyak 39,99\%, setelah dilakukan perbaikan, maka hasil rata-rata aktivitas pembelajaran pada siklus I menunjukkan katagori "cukup sebanyak 59,99\%. Setelah dilakukan perbaikan pada siklus II, maka hasil rata-rata aktivitas siswa meningkatdan menunjukkan katagori "baik" sebanyak 79,99\%. Hal ini menunjukkan bahwa tindakan perbaikan pada siklus dapat mengalami masala yang terjadi. Upaya-upaya perbaikan ini berdampak juga pada peningkatan kemampuan berceritera melalui media gambar seri pada setiap siklus.

Tabel 5.1

Hasil Analisis Nilai Tiap Siklus

\begin{tabular}{|l|c|c|c|}
\hline $\begin{array}{c}\text { Nama } \\
\text { Siswa }\end{array}$ & $\begin{array}{c}\text { Nilai } \\
\text { Awal }\end{array}$ & $\begin{array}{c}\text { Nilai } \\
\text { Siklus I }\end{array}$ & $\begin{array}{c}\text { Nilai } \\
\text { Siklus II }\end{array}$ \\
\hline Dimas & 67,5 & 75 & 85 \\
\hline Fauzi & 65 & 67,5 & 75 \\
\hline ljay & 65 & 65 & 75 \\
\hline Karida & 60 & 65 & 80 \\
\hline Puji & 70 & 75 & 85 \\
\hline
\end{tabular}

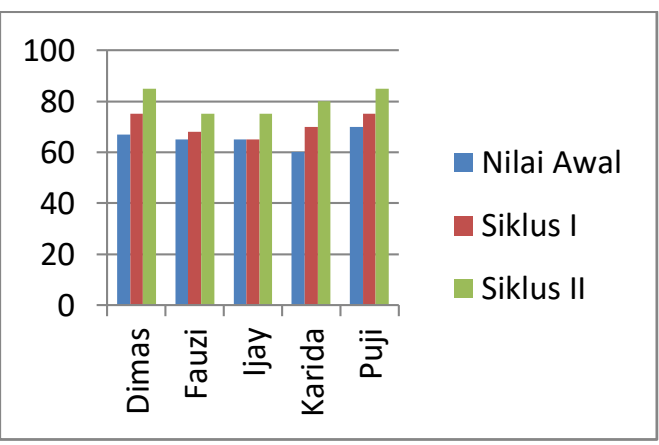

Grafik 1

Presentase Rata-rata Aktivitas Tiap Siklus

Dari grafik diatas dapat dilihat bahwa rata-rata aktivitas siswa tiap siklus mengalami peningkatan. Rata-rata pada awal pembelajaran sebanyak 33,99\%, aktivitas siswa pada siklus I, kemudian mengalami peningkatan sebanyak $55,99 \%$, serta rata-rata aktivitas siswa pada siklus II mengalami peningkatan menjadi $79,99 \%$, sehingga terlihat jelas bahwa tiap siklus mengalami peningkatan dari rata-rata siswa pada setiap siklus.

\section{KESIMPULAN}

Pendidikan merupakan suatu proses untuk mendewasakan individu agar berkebutuhan khusus mempunyai keterampilan dalam segi fisik, kecerdasan, emosi, dan sosialnya sehingga sehingga memerlukan layanan pendidikan secara khusus.

Berdasarkan penelitian tindakan kelas ini, anak tunagrahita masih kesulitan dalam mengikuti pelajaran bahasa Indonesia dengan menggunakan metode role playing serta media gambar masih kurangnya konsentrasi, serta anak mudah jenuh dalam belajar. Setiap kemampuan anak yang berbeda-beda sehingga untuk mengatasi hal seperti itu, guru melakukan upaya-upaya dalam menyampaikan materi yang semenarik mungkin serta diselingi dengan komunikasi dan mengatur posisi tempat duduk agar anak tidak mudah jenuh sehingga dapat berkomunikasi lebih lancar dan siswa menjadi proaktif dalam kegiatan belajar mengajar berlangsung. Dengan menggunakan role playing ini diharapkan peserta didik tunagrahita dapat mengatualisasikan hasil pemikiran yang sederhana terhadap meteri yang diberikan.

Pada umumnya, guru melakukan langkahlangkah pembelajaran dengan benar dan sesuai dengan SKKD seperti melakukan asesmen, merumuskan tujuan, menentukan materi, menentukan metode, membuat media, 
menentukan alokasi waktu, melakukan evaluasi dan mengadakan tindak lanjut. Namun dalam hal pembelajaran bahasa indonesia tentang ceritera dengan menggunakan media gambar yang dibuat harus disesuaikan dengan kemampuan dan kesulitan peserta didik yang bervariasi.

Untuk meningkatkan pelaksanaan pembelajaran bahasa indonesia tentang membaca menguunakan metode role playing serta dengan menggunakan media gambar, sehingga anak tunagrahita di Sekolah Menengah Atas Luar Biasa Kelas XI , guru akan lebih mudah menentukan langkahlangkah dimana diharapkan pesera didik dapat mengikuti pembelajaran secara optimal.

\section{DAFTAR PUSTAKA}

Abin Syamsudin Makmun, (2012), Psikologi Kependidikan, Bandung: PT Rosdakarya

Bandi Delphie, (2006), Pembelajaran Anak Berkebutuhan Khusus dalam setting Pendidikan Inklusi, Bandung: PT Refika Aditama

Departemen Pendidikan Dan Kebudayaan, (2003) Undang-undangDasar N0.2 Tahun 1989 tentang Sistem Pendidikan Nasional, Jakarta: Balai Pustaka

Departemen Pendidikan

Nasional, (2006), KurikulumPendidikan Luar Biasa SDLB,SKKD, Mata Pelajaran Bahasa Indonesia SMPLB Tunagrahita, Jakarta.

Irham Fahmi,SE,M.Si, (2014) Kewirausahaan ,teori, kasus, dan solusi, Bandung: Alfa Beta

Kusnandar,(2010), Langkah Mudah Penelitian Tindakan Kelas Sebagai pengembangan Profesi Guru, Jakarta: Rajagrafindo Persada.

Margono, (2019). Metodologi Penelitian Pendidikan, Jakarta,Rineka Cipta.

Mulyasa Enco, (2012) Penelitian Tindakan Kelas, Bandung: Rosdakarya
Mulyono Abdurrahman, (1996), Pendidikan Anak Berkesulitan Belajar, Jakarta: Departemen pendidikan Dan Kebudayaan Nurchasanah, (2015), Jurus kilat Teknik jahitan Feston, Dunia Kreasi, Jakarta

Suyono,(2011), Belajar dan Pembelajaran, Bandung: PT Remaja 